\title{
Effects of Different Introduction Methods on Plant Species Establishment Success in Wet Grassland Restoration
}

\author{
Bogumila Pawluśkiewicz $^{1 *}$, Maria Janicka², Kazimierz Piekut ${ }^{1}$ \\ ${ }^{1}$ Faculty of Civil and Environmental Engineering, Department of Environmental Improvement, \\ Warsaw University of Life Sciences - SGGW, Warszawa, Poland \\ ${ }^{2}$ Faculty of Agriculture and Biology, Department of Agronomy, Warsaw University of Life Sciences - SGGW, \\ Warszawa, Poland
}

Received: 13 September 2017

Accepted: 18 December 2017

\begin{abstract}
The assessment of plant species' introduction efficiencies for wet meadows was the aim of our study. The studies were carried out as part of a project focusing on flooded meadow restoration in the Middle Vistula Valley. Twenty-six plant species of flooded meadow were in the seedling material used for renovation. The seedbed preparation covered the cutting of vegetation, ploughing, and rototilling, removing the topsoil. The diaspores after seeding were rolled and, on half of the plots, mulched with straw. The number of species, their occurrence frequency, and population abundance as well as the soil coverage by plants in the first year and the third year after diaspora seeding were determined. The seedbed preparation has restricted the occurrence and growth of Solidago sp., and increased soil coverage by meadow species. The share of introduced species in the sward ranged from $5 \%$ to $27 \%$ of coverage. The removal of the sod was significantly more efficient than other methods of seedbed preparation for plant species introduction to the renovated meadows, especially the species characteristic of the Cnidion dubii meadows. Mulching with straw generally has not improved the renovation results. Generally, Sanguisorba officinalis, Achillea millefolium, and Hypericum perforatum were the species of most frequent occurrence.
\end{abstract}

Keywords: wet meadows, restoration, seedbed preparation, meadows species, species occurrence

\section{Introduction}

River valleys are the sites of high biological diversity and high potential of ecosystem services. The significant parts of those valleys are covered by

*e-mail: bogumila_pawluskiewicz@sggw.pl meadow communities of Arrhenatherion elatioris, Molinion caeruleae, and Cnidion dubii meadows. The Cnidion dubii communities occur from southern Russia and through Ukraine, Poland, and eastern Germany into the Panonian basin and Rhine valley of southwestern Germany, France, and alpine regions [1]. In Central Europe the highest area of their presence is presumed to be located in Hungary (about 42000 ha). In Poland the area covered by these meadows is 1640 ha 
and is of a decreasing trend. Cnidion dubii meadows are located in fertile alluvial regions alongside the central and lower valley sections of the great rivers, which are components of the Large Valleys Belt [2]. Due to their regular flooding one or two times a year and dryings between floods they play an important role in the protection of water resources, soils, biodiversity, and landscapes.

In phytosociology the Cnidion dubii Bal.-Tul. 1966 alliance is classified to the order Molinietalia, which belongs to the class Molinio-Arrhenatheretea. The only representative of the Cnidion dubii alliance is the Violo-Cnidietum dubii association. The typical aspect of that association occurs in western Poland [3]. The characteristic species of those meadows, outwith Cnidium dubium, are Allium angulosum, Sanguisorba officinalis, Gratiola officinalis, Scutellaria hastifolia, and Viola stagnina. Cnidion dubii meadows usually occur in mosaic with other types of meadows and rarely occupy vast areas. They are often adjacent to Alopecurion meadows. In the area of lower-lying meadows they bordere Phalaridetum arundinaceae or with various Magnocaricion communities. Cnidion dubii meadows are protected due to a habitat directive (code 6440). The protection of Cnidion dubii meadows results from the fact that the regulation the majority of large rivers as well as their scarcity and diminishment of those sites [4]. Their existence is also conditioned by extensive management, which consists of cutting one or two times annually.

Due to the deterioration of those natural sites in the EU, many activities are being undertaken on their restitution, mostly in Great Britain, Germany, Holland, the Czech Republic, and Estonia [5-11]. The threat for Polish flora, although less significant than in Western European countries, is progressing rapidly [12-14]. The most serious factors comprising threats to the biodiversity of Cnidion dubii meadows is, besides the change of water regime, the abandonment of cutting management. The scale of these threats is reflected by the shrinking surface of the typical associations that are being replaced by incomplete communities and by the disappearance of the species characteristic of associations and alliances [15]. The status of $51 \%$ of Cnidion dubii meadows is estimated as poor and of $27 \%$ as bad [16]. It is absolutely necessary to establish new reserves dedicated to the conservation of the best Cnidion dubii meadows. Protection throughout the agro-environmental schemes and within the framework of Natura 2000 is also a considerable conservation achievement. The necessity of restraining biodiversity loss in the UE is underlined in the the EU Biodivesity Strategy to 2020 [17]. Environmental Liability Directive 2004/35/EC [18] strengthens the preservation of natural resources and ecosystem services, being bound with the Habitat Directive and the Birds Directive [19-20] and creating a system of responsibilities for preventing and harms' repairing regarding biodiversity. Accordingly with the regulations of these directives, the persons and institutions whose activities directly threaten the environment are also responsible for undertaking preventative actions. In Poland, most often the studies of actions are being implemented in the scope of the restoration of xerothermic meadows [21] and fen habitats [22-23], or removing invasive plants - primarily Solidago sp. [24-26].

Property management of the city of Warsaw is stepping toward the needs of restitution of grasslands in the Middle Vistula Valley (PLB 140004) and the restitution of half-open, partially wooded landscapes with a significant share of species-rich meadows of flooded areas of the Vistula River interbank in the area of 67 ha. The restitution for improving the structure and functions of meadow plant communities is connecting, in the case of the lack of soil seedbank, with the introduction of seeds of the most important species and, in following steps, working out the rules of management (type and frequency cutting or grazing) adjusted to the growth rhythm of those species [27-28].

Assessing the possibilities of the introduction of the target species of wet grasslands is the aim of our study.

Table 1. Weather conditions in growing seasons 2015-2016 (Meteorological Station Ursynów-Warsaw).

\begin{tabular}{|c|c|c|c|c|c|c|c|}
\hline \multirow{2}{*}{ Year } & \multicolumn{6}{|c|}{ Month } & \multirow{2}{*}{$\begin{array}{c}\text { Growing season } \\
\text { IV-IX }\end{array}$} \\
\hline & IV & $\mathrm{V}$ & VI & VII & VIII & IX & \\
\hline \multicolumn{8}{|c|}{ Mean temperature $\left({ }^{\circ} \mathrm{C}\right)$} \\
\hline 2015 & 9.1 & 13.7 & 18.1 & 20.5 & 23.0 & 15.6 & 16.7 \\
\hline 2016 & 10.0 & 16.3 & 19.8 & 20.3 & 19.3 & 16.5 & 17.0 \\
\hline \multicolumn{8}{|c|}{ Sum of precipitation $(\mathrm{mm})$} \\
\hline 2015 & 31.4 & 57.7 & 37.5 & 66.2 & 11.3 & 73.1 & 277.2 \\
\hline 2016 & 34.2 & 23.3 & 56.9 & 116.5 & 71.7 & 9.8 & 312.4 \\
\hline \multicolumn{5}{|c|}{ Characteristics of growing seasons } & \multicolumn{3}{|c|}{ Hydrothermal index of Vinczeffy $\left(\sum \mathrm{mm} \cdot \sum^{\circ} \mathrm{C}^{-1}\right)$} \\
\hline 2015 & \multicolumn{4}{|c|}{ Extremely dry } & \multicolumn{3}{|c|}{0.091} \\
\hline 2016 & \multicolumn{4}{|c|}{ Very dry } & \multicolumn{3}{|c|}{0.100} \\
\hline
\end{tabular}


Table 2. Characteristics of introduced plant species.

\begin{tabular}{|c|c|c|c|c|c|c|}
\hline No. & Species & Family & Life form & Durability & Diaspore & Type of seed bank \\
\hline 1 & Achillea millefolium $\mathrm{L}$. & Asteraceae & $\mathrm{H}$ & B & fruit & T, LP \\
\hline 2 & Allium angulosum $\mathrm{L}$. & Amaryllidaceae & G & B & seed & SP \\
\hline 3 & Armeria maritima (Mill.) Willd. & Plumbaginaceae & $\mathrm{H}$ & B & fruit & $\mathrm{T}$ \\
\hline 4 & Artemisia campestris L. & Asteraceae & $\mathrm{C}, \mathrm{H}$ & $\mathrm{B}, \mathrm{S}$ & fruit & T, SP, LP \\
\hline 5 & Centaurea stoebe L. & Asteraceae & $\mathrm{H}$ & $\mathrm{B}, \mathrm{D}$ & fruit & $\mathrm{T}$ \\
\hline 6 & Cnidium dubium (Schkuhr) Thell. & Apiaceae & $\mathrm{H}$ & B & fruit & $\mathrm{T}$ \\
\hline 7 & Dianthus deltoides $\mathrm{L}$. & Caryophyllaceae & $\mathrm{C}$ & B & seed & $\mathrm{T}$ \\
\hline 8 & Eryngium planum $\mathrm{L}$. & Apiaceae & $\mathrm{H}$ & B & fruit & $\mathrm{T}$ \\
\hline 9 & Galium boreale L. & Rubiaceae & $\mathrm{H}$ & B & fruit & $\mathrm{T}$ \\
\hline 10 & Hypericum perforatum $\mathrm{L}$. & Hypericaceae & $\mathrm{H}$ & B & fruit & LP \\
\hline 11 & Inula britannica $\mathrm{L}$. & Asteraceae & $\mathrm{H}$ & B & fruit & $\mathrm{T}, \mathrm{SP}$ \\
\hline 12 & Leucanthemum vulgare Lam. & Asteraceae & $\mathrm{H}$ & B & fruit & SP, LP \\
\hline 13 & Linaria vulgaris Mill. & Plantaginaceae & $\mathrm{G}, \mathrm{H}$ & B & seed & $\mathrm{T}, \mathrm{SP}$ \\
\hline 14 & Lysimachia vulgaris L. & Primulaceae & $\mathrm{H}$ & B & seed & T, SP, LP \\
\hline 15 & Lythrum salicaria L.. & Lythraceae & $\mathrm{H}$ & B & seed & T, SP, LP \\
\hline 16 & Plantago lanceolata L.. & Plantaginaceae & $\mathrm{H}$ & B & seed & LP \\
\hline 17 & Potentilla erecta (L.) Raeusch. & Rosaceae & $\mathrm{H}$ & B & fruit segments & $\mathrm{T}, \mathrm{SP}$ \\
\hline 18 & Rumex acetosa $\mathrm{L}$. & Polygonaceae & $\mathrm{H}$ & B & fruit & SP \\
\hline 19 & Sanguisorba officinalis L. & Rosaceae & $\mathrm{H}$ & B & fruit & $\mathrm{T}$ \\
\hline 20 & Scabiosa ochroleuca L. & Dipsacaceae & $\mathrm{H}$ & $\mathrm{B}, \mathrm{D}$ & fruit & LP \\
\hline 21 & Thalictrum flavum L. & Ranunculaceae & $\mathrm{H}$ & B & fruit & $\mathrm{T}$ \\
\hline 22 & Tragopogon pratensis L. & Asteraceae & $\mathrm{H}$ & $\mathrm{D}$ & fruit & $\mathrm{T}$ \\
\hline 23 & Trifolium arvense L. & Fabaceae & $\mathrm{T}, \mathrm{H}$ & A, D & seed & LP, T \\
\hline 24 & Verbascum thapsus L. & Scrophulariaceae & $\mathrm{H}$ & $\mathrm{D}$ & seed & LP, T \\
\hline 25 & Veronica longifolia $\mathrm{L}$. & Plantaginaceae & $\mathrm{H}$ & B & seed & $\mathrm{T}, \mathrm{SP}$ \\
\hline 26 & Veronica spicata L. & Plantaginaceae & $\mathrm{C}, \mathrm{H}$ & B & seed & $\mathrm{T}, \mathrm{LP}$ \\
\hline
\end{tabular}

Life form: $\mathrm{H}$ - hemicryptophyte, $\mathrm{G}$ - geophyte, $\mathrm{C}$ - herbaceous chamaephyte, $\mathrm{T}$ - therophyte. Durability: B - perennial, $\mathrm{D}$ - biennial plant, $\mathrm{S}-$ subshrub. Type of seed bank: $\mathrm{LP}=$ long-term persistent, $\mathrm{SP}=$ short-term persistent, $\mathrm{T}=$ transient

\section{Material and Methods}

The studies were carried out in the Vistula River interbank on Białołęka object (geographical coordinates: $52^{\circ} 29^{\prime} \mathrm{N} ; 20^{\circ} 96^{\prime}$ E) in 2014-2017. The studies were carried out as part of the "Restitution of the flooded meadows on Warsaw cross-section of Natura 2000 site Middle Vistula Valley (PLB 140004)" project.

The soil is averagely coherent with grain size distribution of the silt sand originating from the loam. In the $0-20 \mathrm{~cm}$ layer of the soil rubbish occurs, because storage of construction materials began in 1979. That area is being flooded at high water levels.

Weather conditions in the study period were not convenient for plant development. The value of
Vinczeffy [29] hydrothermal index, calculated as the quotient of total precipitation to the sum of temperature, was very low for growing season 2015 and amounted to $0.091 \mathrm{~mm}{ }^{\circ} \mathrm{C}^{-1}$, which means an extremely dry season (Table 1). The growing season of 2016 was not as dry as in 2015, but the rain distribution was very unfavorable. The value of the Vinczeffy hydrothermal index for growing season 2016 amounted $0.100 \mathrm{~mm}^{\circ} \mathrm{C}^{-1}$, which points to the period being very dry. With the exception of a wet July, in which the precipitation was equal to $0.185 \mathrm{~mm}$ per $1^{\circ} \mathrm{C}$, remaining months of the growing season were very dry. May and September were extremely dry, wich hydrothermal indexes amounting to, respectively, 0.046 and $0.020 \mathrm{~mm}^{\circ} \mathrm{C}^{-1}$. 
The area was used as meadow and pasture (cattle and horse grazing). The construction of Tarchomin house settlement and the abandonment of mowing and grazing resulted in a succession of trees and shrubs and massive development of Solidago sp. (alien invasive) and Erigeron annuus (anthropophyte, domesticated, invasive). Preparation of the terrain for experiment covered the cuttings of a few trees and two clumps of A. negundo of less than 10 years old, and vegetation mowing.

We introduced 26 plant species of Cnidion dubii meadows (6440), taken from well preserved natural sites from the neighborhood of Warsaw (lower Pilica Valley: PLH 140016, 51 ${ }^{\circ} 51^{\prime} \mathrm{N} ; 2^{\circ} 15^{\prime} \mathrm{E}$ and 51 ${ }^{\circ} 50^{\prime}$ $\left.\mathrm{N} ; 21^{\circ} 17^{\prime} \mathrm{E}\right)$. The characteristics of introduced plant species and type of seed bank persistence according to Thompson [30] are presented in Table 2. The diaspores were harvested by hand on 23.09.2014. The seed rate of seedling material (diaspores with the inflorescences) was equal to $10 \mathrm{~g} \mathrm{~m}^{-2}$, which corresponds to the recommendations of 2-5,000 of the diasporas per $1 \mathrm{~m}^{2}$ [31].

In the experiment three ways of seedbed preparation were applied: 1) low cutting of vegetation, 2) ploughing to a depth about $20 \mathrm{~cm}$ and rototilling without surface leveling, and 3) removal the sward and topsoil $(30 \mathrm{~cm}$ layer). In each variant two methods of diaspore sowing were applied: 1) sowing without straw mulching and 2) sowing with a thin layer of rye straw coverage and control variant without sowing for assessment of a soil's seed bank. The diaspores were sown by hand onto the prepared areas and rolled on with a light roller on 25 October 2014. The experiment was carried out on the plots $(10 \mathrm{~m} \times 12 \mathrm{~m})$ with six replications. The plots in the sequence of the belts with various seedbed preparation were drawn, and the methods of sowing were arranged in split plot. The total number of plots was 54 (Fig. 1).

In mid-July 2015, before the flowering of Solidago sp., the cultivation cut was made at a height of $25 \mathrm{~cm}$. In subsequent years the mowings were done once a year, in autumn.

Within the framework of the study, the effectiveness of restricting the invasive species share in the sward and the abundance of the sown species population were analyzed. The assessment of plants during vegetation period 2015 was carried out every month on $1 \mathrm{~m}^{2}$ area (1 $\mathrm{m} \times 1 \mathrm{~m}$, micro plot), with 6 replications of each investigated variant. The total number of sown species was registered and the quantity of species population was expressed in scale 1-6 (where 6 is the number of occurrences of the species on all plots, and 1 is the occurrence on one plot). The abundance of population was determined on points scale $0-5$ on the basis of their occurrence in the sward ( 0 is lack of plants, 1 is single, 2 is group, 3 is pretty numerous, 4 is numerous, and 5 is very numerous).

The assessment of groundcover with plants was determined. The botanical composition of the sward was determined by noting the occurring species and the percentage of invasive and dominant ones. The state of the sward in spring 2017 was assessed not on micro plots, but on the entire area of particular tested treatment.

The obtained results of measurement and values of scale grades were analyzed statistically using the variance analysis (ANOVA). The verification of the difference significance was based on Tukey's test on the level of confidence 0.05 .

\section{Results and Discussion}

The survey of the floristic composition of the sward, carried out in 2015, showed the presence of 17 species from 26 sown ones. The similar effectiveness of the introduction (total number of target species in the range 51.5-57.6) was obtained for the Molinion meadows in Wielkopolska Lowland [1]. The species number was affected by the method of seedbed preparation (Table 3). The lowest number of species was noted on plough and plots, independently from the method of diaspore coverage (12 in total), but the lowest one on the variant with removed topsoil (16-17 in total). The mean number was 2-3 times lower and amounted from 4 to 8 (on average 6) species.

The best conditions for the development of most species and frequency of their occurrence were noted in the variant with removed topsoil without straw mulching, where eight species have developed (Table 4). Among them were the four characteristic of Cnidion dubii meadows (A. angulosum, S. officinalis, G. boreale and $C$. dubium), two of Arrhenatherion meadows (A. millefolium, P. lanceolata), and two of dry meadows (A. campestris, H. perforatum). A particularly high

\begin{tabular}{|c|c|c|}
\hline Removed topsoil without sowing & Ploughing and rototilling without sowing & Cutting of sward without sowing \\
\hline $\begin{array}{c}\text { Removed topsoil without straw } \\
\text { mulching }\end{array}$ & $\begin{array}{r}\text { Ploughing and rototilling without straw } \\
\text { mulching }\end{array}$ & Cutting of sward without straw mulching \\
\hline $\begin{array}{c}\text { Removed topsoil with straw } \\
\text { mulching }\end{array}$ & $\begin{array}{c}\text { Ploughing and rototilling } \\
\text { with straw mulching }\end{array}$ & Cutting of sward with straw mulching \\
\hline $2 \mathrm{~m}$ & $4 \mathrm{~m}$ & $4 \mathrm{~m}$ \\
\hline
\end{tabular}

Fig 1. Scheme of the experiment. 
Table 3. Number of introduced species depending on seedbed preparation and the sowing methods in 2015 and 2017.

\begin{tabular}{|c|c|c|c|c|c|c|}
\hline \multirow{3}{*}{ Number species } & \multicolumn{2}{|c|}{ Cutting of sward } & \multicolumn{2}{|c|}{ Ploughing and rototilling } & \multicolumn{2}{|c|}{ Removed topsoil } \\
\hline & \multicolumn{6}{|c|}{ Straw mulching } \\
\hline & yes & no & yes & no & yes & no \\
\hline \multicolumn{7}{|c|}{ Year 2015} \\
\hline Total & 14 & 14 & 12 & 12 & 17 & 16 \\
\hline Mean & $6 a b$ & $6 a b$ & $4 a$ & $6 a b$ & $7 \mathrm{ab}$ & $8 b c$ \\
\hline \multicolumn{7}{|c|}{ Year 2017} \\
\hline Total & 12 & 13 & 10 & 10 & 14 & 14 \\
\hline Mean & $6 a b$ & $6 a b$ & $5 \mathrm{a}$ & $6 a b$ & $8 \mathrm{ab}$ & $9 b c$ \\
\hline
\end{tabular}

occurrence was shown by $A$. angulosum and S. officinalis (6 and 5,7 points on a 1-6 scale) in that the variant of seedbed preparation before sowing. Topsoil removal, which leads to lowering of the soil surface and reduces the distance from groundwater, may be used to provide hydrological conditions, which are adequate for target species [31-32]. Ploughing without mulching favored the growth of the same species as the removal of the topsoil layer, but with the frequency lower by about $30 \%$ on average. In the case of that method of soil preparation the biggest frequency of the occurrence (5 points in 1-6 scale) was shown by 2 species characteristic of Cnidium dubii meadows: $S$. officinalis and $C$. dubium. Lower frequency of occurrence was characteristic for the species on mown plots, uncovered by straw (averaging 3.7 pts. on a $1-6$ scale).

Mulch coverage limited the number and the occurrence frequency of the species. In the variants with mowing and ploughing only 3 species (S. officinalis, A. millefolium, C. dubium) were stated, with the occurrence equal to at least 3 points (on a 1-6 scale). The mulching in the variant with removed soil created better conditions for initial growth of the sown species. In such conditions the occurrence of the 7 species, with frequency from 3,7 to 5 pts. on a 1-6 scale. The highest values of this parameter were typical for A. angulosum,
A. millefolium, and A. campestris - species characterized by various demands for water conditions (periodically wet, fresh, or dry sites). It is in accordance with other studies reported that the dead plant material (litter) had an overall negative effect on seed germination and seedling establishment [33], which creates a mechanical barrier to seedling emergence and causes a change in physical conditions (light, moisture, and temperature regimes), and can also release allelochemicals, which may be toxic. In flooded grasslands, the effects of the litter were neutral or negative, because high soil moisture levels in litter for longer periods of time might also promote the development of pathogens, which may increase seedling mortality [34]. The results obtained by Eckstein and Donath [35] suggest that the transfer of seed-containing plant litter may support the restoration projects if applied at $0.2-0.4 \mathrm{~kg} \mathrm{~m}^{-2}$. Below that range, the establishment of most species may be inhibited by drought, while higher amounts would increasingly suppress the emergence of the seedlings, especially of small-seeded species.

Statistical analysis of the occurrence frequency of four characteristic species of Cnidion dubii meadows in dependence on the method of restitution has not shown the significant differences only in the variant with vegetation cutting (Table 5). In the variant with

Table 4. Frequency of occurrence of introduced species depending on seedbed preparation in 2015; the table contains only species with the highest frequency of occurrence $\left(\geq 3.0\right.$ according to $6^{\circ}$ scale).

\begin{tabular}{|c|c|c|}
\hline \multirow{2}{*}{$\begin{array}{l}\text { Introduction } \\
\text { method }\end{array}$} & \multicolumn{2}{|c|}{ Straw mulching } \\
\hline & Yes & No \\
\hline Cutting of sward & S. officinalis (4.5), A. millefolium (3.3) & $\begin{array}{l}\text { S. officinalis (4.0), A. millefolium (4.0), } \\
\text { C. dubium (3.7), G. boreale (3.7), } \\
\text { H. perforatum (3.0) A. angulosum (3.0) }\end{array}$ \\
\hline $\begin{array}{l}\text { Ploughing } \\
\text { and rototilling }\end{array}$ & C. dubium (3.0), S. officinalis (3.0) & $\begin{array}{l}\text { S. officinalis (5.3), C. dubium (5.0), } \\
\text { P. lanceolate (4.3), A. millefolium ( } 3.7) \text {, } \\
\text { A. campestris (3.3) A. angulosum (3.0), } \\
\text { G. boreale (3.0), H. perforatum (3.0) }\end{array}$ \\
\hline Removed topsoil & $\begin{array}{l}\text { A. angulosum (5.0), A. millefolium (5.0), A. campestris (5.0), } \\
\text { S. officinalis (4.7), } \\
\text { H. perforatum (4.7), P. lanceolata (4.0), G. boreale (3.7) }\end{array}$ & $\begin{array}{l}\text { A. angulosum (6.0), S. officinalis (5.7), } \\
\text { A. campestris (5.3), H. perforatum (5.0), } \\
\text { G. boreale (4.7), P. lanceolata (4.3), } \\
\text { A. millefolium (4.0), C. dubium (3.7) }\end{array}$ \\
\hline
\end{tabular}


Table 5.The frequency of occurrence of the species characteristic of Cnidion dubii meadows in dependence on the introduction method in 2015 (scale 1-6 points).

\begin{tabular}{|c|c|c|c|c|c|}
\hline Introduction method & $\begin{array}{c}\text { Allium } \\
\text { angulosum }\end{array}$ & Cnidiumdubium & Galiumboreale & $\begin{array}{c}\text { Sanguisorba- } \\
\text { officinalis }\end{array}$ & Mean \\
\hline Cutting of sward with straw mulching & $2.3 a^{*}$ & $1.7 \mathrm{a}$ & $2.0 \mathrm{a}$ & $4.5 \mathrm{a}$ & $2.6 \mathrm{~B}$ \\
\hline Cutting of sward without straw mulching & $3.0 \mathrm{a}$ & $3.7 \mathrm{a}$ & $3.7 \mathrm{a}$ & $4.0 \mathrm{a}$ & 3.6B \\
\hline Cutting of sward without sowing & $0,7 \mathrm{a}$ & $0.0 \mathrm{a}$ & $0.7 \mathrm{a}$ & $0.7 \mathrm{a}$ & $0.5 \mathrm{~A}$ \\
\hline Ploughing and rototilling with straw mulching & $1.0 \mathrm{a}$ & $3.0 \mathrm{~b}$ & $2.7 b$ & $3.0 \mathrm{~b}$ & 2.4B \\
\hline Ploughing and rototilling without straw mulching & $3.0 \mathrm{a}$ & $5.0 \mathrm{~b}$ & $3.0 \mathrm{a}$ & $5.3 b$ & 4.1 C \\
\hline Ploughing and rototilling without sowing & $0.7 \mathrm{a}$ & $0.0 \mathrm{a}$ & $0.7 \mathrm{a}$ & $0.7 \mathrm{a}$ & $0.5 \mathrm{~A}$ \\
\hline Removed topsoil with straw mulching & $5.0 \mathrm{~b}$ & $1.0 \mathrm{a}$ & $3.7 \mathrm{~b}$ & $4.7 b$ & $3.6 \mathrm{~B}$ \\
\hline Removed topsoil without straw mulching & $6.0 \mathrm{~b}$ & $3.7 \mathrm{a}$ & $4.7 \mathrm{ab}$ & $5.7 b$ & $5.0 \mathrm{C}$ \\
\hline Removed topsoil without sowing & $0.7 \mathrm{a}$ & $0.0 \mathrm{a}$ & $0.0 \mathrm{a}$ & $0.7 \mathrm{a}$ & $0.3 \mathrm{~A}$ \\
\hline Mean & $2.5 \mathrm{AB} * *$ & $2.0 \mathrm{~A}$ & $2.3 \mathrm{AB}$ & $3.2 \mathrm{~B}$ & \\
\hline
\end{tabular}

*a-c the same letters in rows are not significantly different; **A-C the same letters in rows and in columns (for mean) are not significantly different

Table 6. Population abundance in dependence on seedbed preparation and the methods of sowing in 2015 and 2017 (average values for the plots where the species occurred, according to a 5-point scale).

\begin{tabular}{|c|c|c|c|c|c|c|c|}
\hline \multirow{3}{*}{ Introduction method } & \multicolumn{2}{|c|}{ Cutting of sward } & \multicolumn{2}{|c|}{ Ploughing and rototilling } & \multicolumn{2}{|c|}{ Removed topsoil } & \multirow{3}{*}{ Mean } \\
\hline & \multicolumn{6}{|c|}{ Straw mulching } & \\
\hline & yes & no & yes & no & yes & no & \\
\hline Species & \multicolumn{7}{|c|}{ Year 2015} \\
\hline A. millefolium & 1.0 & 3.5 & 1.5 & 1.0 & 3.2 & 3.3 & $2.2 \mathrm{~d}^{*}$ \\
\hline A. angulosum & 4.0 & 3.6 & 2.0 & 1.7 & 2.7 & 2.4 & $2.7 \mathrm{de}$ \\
\hline A. campestris & 1.0 & 2.0 & 1.0 & 1.0 & 2.7 & 2.7 & $1.7 \mathrm{~cd}$ \\
\hline C. dubium & 2.0 & 2.0 & 1.0 & 2.5 & 1.0 & 1.0 & $1.6 \mathrm{~cd}$ \\
\hline D. deltoides & - & - & - & - & 1.0 & 1.0 & $0.3 \mathrm{a}$ \\
\hline E. planum & 1.0 & 1.0 & 1.0 & 1.0 & 1.5 & 1.0 & $1.1 b c$ \\
\hline G. boreale & 1.0 & 1.0 & 1.5 & 2.0 & 1.0 & 1.0 & $1.2 \mathrm{~b}$ \\
\hline H. perforatum & 1.0 & 2.0 & 3.0 & 2.0 & 2.5 & 2.5 & $2.2 \mathrm{~d}$ \\
\hline L. vulgare & 1.0 & 1.0 & - & - & 1.0 & 1.0 & $0.7 \mathrm{ab}$ \\
\hline P. lanceolata & 1.0 & 2.5 & 1.0 & 1.0 & 1.0 & 2.5 & $1.5 \mathrm{c}$ \\
\hline P. erecta & 1.0 & 1.0 & 1.5 & 1.0 & 1.0 & 1.0 & $1.1 b c$ \\
\hline R. acetosa & - & 1.0 & - & 1.0 & 1.0 & 1.0 & $0.7 \mathrm{ab}$ \\
\hline S. officinalis & 1.0 & 3.0 & 1.0 & 1.5 & 1.5 & 1.5 & $1.6 \mathrm{c}$ \\
\hline S. ochroleuca & - & 1.0 & - & 1.0 & 1.0 & 1.0 & $0.7 \mathrm{ab}$ \\
\hline T. pratensis & 1.0 & 1.0 & - & - & 1.0 & 1.0 & $0.7 \mathrm{ab}$ \\
\hline V. thapsus & 1.0 & - & 1.0 & - & 3.2 & 1.0 & $1.0 \mathrm{~b}$ \\
\hline V. longifolia & 1.0 & - & - & - & 1.0 & - & $0.3 \mathrm{a}$ \\
\hline Mean & $1.1 \mathrm{a}^{*}$ & $1.5 \mathrm{~b}$ & $0.9 \mathrm{a}$ & $1.0 \mathrm{a}$ & $1.7 \mathrm{~b}$ & $1.5 \mathrm{~b}$ & \\
\hline Species & \multicolumn{7}{|c|}{ Year 2017} \\
\hline A. millefolium & 2.2 & 2.6 & 2.3 & 2.3 & 3.2 & 3.9 & $2.8 \mathrm{~d}$ \\
\hline
\end{tabular}


Table 6. Continued.

\begin{tabular}{|c|c|c|c|c|c|c|c|}
\hline A. angulosum & - & - & - & - & 1.0 & - & $0.2 \mathrm{a}$ \\
\hline A. campestris & 1.0 & 1.0 & 1.0 & 1.2 & 1.9 & 2.5 & $1.4 \mathrm{bc}$ \\
\hline C. dubium & 1.2 & 1.0 & 1.2 & 1.0 & 1.0 & - & $0.9 \mathrm{ab}$ \\
\hline D. deltoides & - & - & - & - & 1.0 & 1.9 & $0.5 \mathrm{ab}$ \\
\hline E. planum & 1.0 & 1.4 & 1.0 & 1.2 & 2.0 & 1.6 & $1.4 \mathrm{bc}$ \\
\hline G. boreale & 1.0 & 2.0 & 1.0 & 1.0 & 1.5 & 1.0 & $1.2 \mathrm{~b}$ \\
\hline H. perforatum & 3.2 & 2.3 & 2.2 & 1.8 & 2.1 & 2.2 & $2.3 \mathrm{~d}$ \\
\hline L. vulgare & 2.0 & 1.0 & - & - & 1.0 & 1.2 & $0.9 \mathrm{ab}$ \\
\hline P. lanceolata & 1.6 & 1.2 & 1.5 & 1.5 & 1.6 & 1.4 & $1.9 \mathrm{~cd}$ \\
\hline P. erecta & 2.2 & 1.0 & 1.8 & 1.2 & 1.6 & 1.2 & $1.5 \mathrm{c}$ \\
\hline R. acetosa & - & 1.0 & - & - & - & 1.0 & $0.3 \mathrm{a}$ \\
\hline S. officinalis & 1.0 & 1.6 & 1.2 & 1.3 & 1.8 & 1.6 & $1.4 \mathrm{bc}$ \\
\hline S. ochroleuca & - & 1.0 & - & 1.0 & - & 1.0 & $0.5 \mathrm{ab}$ \\
\hline T. pratensis & 1.0 & 1.0 & - & - & - & 1.0 & $0.5 \mathrm{ab}$ \\
\hline V. thapsus & 1.0 & - & 1.0 & - & 2.5 & 1.2 & $0.9 \mathrm{ab}$ \\
\hline V. longifolia & - & - & - & - & 1.0 & - & $0.2 \mathrm{a}$ \\
\hline Mean & $1.1 \mathrm{~b}$ & $1.1 \mathrm{~b}$ & $0.8 \mathrm{a}$ & $0.8 \mathrm{a}$ & $1.4 \mathrm{c}$ & $1.3 \mathrm{bc}$ & \\
\hline
\end{tabular}

*a-d the same letters in rows and in columns (for mean) are not significantly different

plough and rototilling a significantly lower frequency was shown by $A$. angulosum, and in variant without mulching also by $G$. boreale. The mentioned species occurred with more than $40 \%$ lower frequency than C. dubium and $S$. officinalis. In the variants with removed soil $C$. dubium developed in the weakest form, especially on mulching plots. It occurred averagely over twofold seldom than other species in that group (A. angulosum, G. boreale, S. officinalis). On the control areas the species of Cnidion dubii, meadows occurred sporadically. The analysis of mean values of the species occurrence frequency allowed for the distinction of two groups of the methods of Cnidion dubii meadows renovation. The methods of the best effect in the first period after seeding were topsoil removal and plough without mulching. Irrespective of the method, the highest statistical frequency of occurrence was shown by $S$. officinalis, and the lowest by $C$. dubium, which may be connected with species diaspora sizes as the result of previous studies showing that smaller-seeded species tend to have higher light demands for germination. The ones of C. dubium are about 5-times smaller and characterized themselves by lesser germination ability than the diasporas of $S$. officinalis [36, 37].

It should be underlined that in the case of $C$. dubium the best effects of restitution are given by ploughing without mulching, which probably originates from that species' reaction on nitrogen release due to the mineralization of the organic substrate after cultivation [38]. The restoration effects of A. angulosum and
G. boreale were similar. Both of them showed the best occurrence frequency in the variant with removed sod without mulching.

In 2015 the sown species differenced themselves not only by occurrence frequency but also by population abundance (Table 6). The best development was shown by one species of Cnidion dubii meadows - A. angulosum, especially in the variant with cutting (3.6, 4.0 pts. in the scale 0-5), one of the Arrhenatherion meadows $-A$. millefolium, and one of dry meadows - H. perforatum (2.2 pts. on average.). The lower abundances (1.5-1.7 pts. in average) were shown by two species of Cnidion dubii meadows (C. dubium and $S$. officinalis), one species of Arrhenatherion meadows (P. lanceolata), and one of dry meadows (A. compestris). The significant abundance was noted also in the case of $V$. thapsus, but only on the plots with removed sod and mulching (3.2 points). The recent studies indicated that under dry conditions (e.g., dry grasslands or dry periods) the presence of dead plant tissues had a positive effect on seedling establishment [34]. The remaining species occurred singly. Among them, D. deltoides occurred only in the variant with removed sod, but $L$. vulgare and T. pratensis occurred in all variants with the exception of ploughing.

The species seeded in the variant with removed sod and cutting without mulching characterized themselves by significantly higher population abundance. The second group of methods were the variants with plough and cutting with mulching 
Table 7. Soil coverage (\%) depending on the introduction method in 2015 and 2017.

\begin{tabular}{|c|c|c|c|c|c|c|c|}
\hline & \multicolumn{3}{|c|}{ Year 2015 } & \multicolumn{3}{c|}{ Year 2017 } \\
\hline Introduction method & $\begin{array}{c}\text { Solidago } \\
\text { sp. }\end{array}$ & $\begin{array}{c}\text { Other } \\
\text { species }\end{array}$ & $\begin{array}{c}\text { Total } \\
\text { coverage }\end{array}$ & $\begin{array}{c}\text { Solidago } \\
\text { sp. }\end{array}$ & $\begin{array}{c}\text { Introduced } \\
\text { species }\end{array}$ & $\begin{array}{c}\text { Other } \\
\text { species }\end{array}$ & $\begin{array}{c}\text { Total } \\
\text { coverage }\end{array}$ \\
\hline Cutting of sward with straw mulching & $14.2 \mathrm{~b} *$ & $16.2 \mathrm{ab}$ & $30.4 \mathrm{c}$ & $35.0 \mathrm{c}$ & $7.5 \mathrm{ab}$ & $52.5 \mathrm{c}$ & $60.0 \mathrm{~b}$ \\
\hline Cutting of sward without straw mulching & $14.8 \mathrm{~b}$ & $18.1 \mathrm{~b}$ & $32.9 \mathrm{c}$ & $7.5 \mathrm{a}$ & $5.0 \mathrm{a}$ & $45.0 \mathrm{c}$ & $50.0 \mathrm{~b}$ \\
\hline Cutting of sward without sowing & $13.5 \mathrm{~b}$ & $13.7 \mathrm{ab}$ & $27.2 \mathrm{~b}$ & $11.5 \mathrm{~b}$ & $0.7 \mathrm{a}$ & $34.3 \mathrm{c}$ & $35.0 \mathrm{a}$ \\
\hline $\begin{array}{c}\text { Ploughing and rototilling } \\
\text { with straw mulching }\end{array}$ & $12.4 \mathrm{~b}$ & $13.3 \mathrm{ab}$ & $25.7 \mathrm{~b}$ & $11.0 \mathrm{~b}$ & $10.5 \mathrm{~b}$ & $29.5 \mathrm{~b}$ & $40.0 \mathrm{a}$ \\
\hline $\begin{array}{c}\text { Ploughing and rototilling without straw } \\
\text { mulching }\end{array}$ & $12.9 \mathrm{~b}$ & $19.3 \mathrm{~b}$ & $32.2 \mathrm{c}$ & $5.0 \mathrm{a}$ & $8.5 \mathrm{~b}$ & $29.0 \mathrm{~b}$ & $37.5 \mathrm{a}$ \\
\hline Ploughing and rototilling without sowing & $16.3 \mathrm{~b}$ & $15.7 \mathrm{ab}$ & $32.0 \mathrm{c}$ & $11.5 \mathrm{~b}$ & $1.0 \mathrm{a}$ & $29.0 \mathrm{~b}$ & $30.0 \mathrm{a}$ \\
\hline Removed topsoil with straw mulching & $0.2 \mathrm{a}$ & $18.0 \mathrm{~b}$ & $18.2 \mathrm{ab}$ & $1.0 \mathrm{a}$ & $26.7 \mathrm{~d}$ & $15.8 \mathrm{a}$ & $42.5 \mathrm{a}$ \\
\hline Removed topsoil without straw mulching & $0.1 \mathrm{a}$ & $15.4 \mathrm{ab}$ & $15.5 \mathrm{ab}$ & $0.0 \mathrm{a}$ & $19.0 \mathrm{c}$ & $26.0 \mathrm{~b}$ & $45.0 \mathrm{a}$ \\
\hline Removed topsoil without sowing & $0.0 \mathrm{a}$ & $6.7 \mathrm{a}$ & $6.7 \mathrm{a}$ & $10.0 \mathrm{~b}$ & 7.5 & $27.5 \mathrm{~b}$ & $35.0 \mathrm{a}$ \\
\hline
\end{tabular}

*a-d the same letters in columns are not significantly different

(1.0 point in average). The relatively low abundance of the seeded species was effected by the lack of introduced species in soil coverage in 2015 (Table 7).

The number of introduced species and their population abundance decreased in the investigation period (Tables 3, 6). In spring 2017 the number of species was about 1-3 species lower on average, and the mean a little bit higher ( 7 on average, from 5 to 9) than in 2015. Similarly to 2015, the majority of the species sown in 2017 were found on the variant with removed topsoil without straw mulching (14 species), but the minority on the cultivated plots - plough and rototilling (10 species). The significant differences in species number were stated only for the variant with removed sod without mulching and the one with ploughing and mulching. The decrease in the species number in time was stated also by [1]. But in some investigations the increase in the number of the species developed from the diasporas after a longer period of domination was noticed [39]. According to that paper, four years after the transfer of plant material a total of 92 species had successfully been established, among them 25 of the Red List.

Among the species typical of Cnidion dubii meadows the distinctive regress from the sward was shown by $A$. angulosum, which could be caused by long drought (Table 6). Despite the significant abundance of that species in the variant with vegetation cutting, after two years its presence was not proved, and in variant with removed sod it occurred singly. Almost twofold lower (in average) population abundance in 2017 was shown by $C$. dubium - the second characteristic species of Cnidion dubii meadows. The status of the G. boreale and $S$. officinale populations remained on a similar level as two years before.

Beside the species characteristic for Cnidion dubii meadows in peculiar variants the regression of
$R$. acetosa, S. ochroleuca and $V$. longifolia was stated Those species occurred singly in 2015. The difficulties with the introduction and keeping the target species were pointed out by foreign studies [40-43]. Renovation of the wet and fen meadows is especially difficult [22, 44]. The removal of even a $50-\mathrm{cm}$ layer of soil is being proposed for effective introduction of some plant species [31].

In 2017 not only the decrease but also the increase in the population abundance of the introduced species were stated. The species of Cnidion dubii (the community in regress) were replaced by the ones of Arrhenatherion meadows, especially A. millefolium (in variant with ploughing) and $P$. lanceolata. In the variant with removed sod the density of $D$. deltoides increased almost twofold, and the density of E. planum population of $30 \%$. In the variant with vegetation cutting and mulching the population of $H$. perforatum and $P$. erecta increased 2-3 fold. Regardless of the individual species, the significantly larger population abundance in 2017 was typical for the areas with removed sod and the ones mowed without mulching. The mentioned methods may be consisted as one homogenic group. In the variant with removed sod that value averaged about $16 \%$ less, but the variant with vegetation mowing was about $36 \%$ bigger than in 2015. In the second homogenic group of methods, the mean population abundance was equal to 1 point on average and of about 10\% lower than in 2015 . It is difficult to estimate the obtained results because of a lack of studies concerning the individual species. As a rule the total number of the introduced species and the total coverage are given. For example, the total number of the species increased significantly in the restored semi-natural grasslands between 2001 and 2012, from 51.8 to 62.9 per site [45]. Because of various tolerance of the species for changing environmental conditions, the studies of individual species may 
contribute to the success of community restoration [46-48].

The share of introducing species in the sward in the first year after sowing (2015) was low, most often below $1 \%$, sporadically $5-7 \%$. In spring 2017 their share was significant. They constituted from $5 \%$ to about $27 \%$ on sown areas (Table 7). Statistically the highest share of these plants was typical for the swards on the plots with removed topsoil. The sown species there constituted $64 \%$ of soil coverage on treatment with mulch and $42 \%$ without mulching. It should be pointed out that the share of introduced species on the plots without sowing was relatively high $(7.5 \%)$, which testifies to the occurrence of these species diaspores in soil. These species were A. millefolium, $H$. perforatum, and $P$. erecta. These are the ones characteristic of drying habitats but not indicative species for Cnidion dubii meadows.

The decrease in the invasive species share, especially the high one of Solidago sp., increased soil coverage from about $26 \%$ to $46 \%$ on average (Table 7). The development of Solidago was most effectively restrained by removing of surface layer of soil. Besides the introduced species in the sward, the typical meadow species come into sight, grasses (Arrhenatherum elatius, Elymus repens, Calamagrostis epigejos, Poa pratensis, Poa palustris) and Fabaceae plants (Medicago lupulina, Trifolium repens, Trifolium pratense, Vicia sepium). The fast development of expansive species like $C$. epigejos and E. repens, which gradually increased their shares in the sward, threatens the development of the introduced species. Many target species exhibited low recruitment rates because their ability to disperse in time and space is low.

\section{Conclusions}

The investigated methods of meadow renovation on the studied area of the Middle Vistula Valley generally allowed restraining the Solidago sp. occurrence in plant communities in order to improve the botanical composition of the sward and to increase the terrain coverage by the meadow plants. The introduced species after three years since sowing covered from $5 \%$ to $27 \%$ of the area.

The effectivities of meadow species introduction depended on the intensity of seedbed preparation and the method of diaspora sowing. The removal of sod was the best way for the reduction of Solidago sp. occupation at the meadows. The number of introduced species was the highest (17) and their occurrence frequency was high.

The species characteristic for Cnidion dubii meadows - Allium angulosum, Cnidium dubium, Galium boreale, and Sanguisorba officinalis - initially had developed best on the variant with removed sod, with plough and rototilling but without mulching. A. angulosum and C. dubium, despite pretty well results in the first year, quickly retreated from the sward, which shows that their occurrence at a higher degree depends on keeping the regime of water conditions than in the case of the rest of the species of that group.

The relatively simply introduction of Sanguisorba officinalis in wet sites, Achillea millefolium in moist sites, and Hypericum perforatum in drying sites shows the higher possibility of enriching the meadows with one or few species.

\section{Acknowledgements}

The work was performed within the framework of Statutory Activity of the Department Environmental Improvement and Agronomy Department Warsaw University of Life Sciences under the task "Restoration of protected meadow communities on valuable natural sites."

\section{Conflict of Interest}

The authors declare no conflict of interest.

\section{References}

1. SCOTTON T., KIRMER A., KRAUTZER B MANN S., STOLLE M.,., GRAISS W., HASLGRÜBLER P., ŠEVČIKOVA M., SCOTTON M. (Eds.) Practical handbook for seed harvest and ecological restoration of species-rich grasslands. CLEUP, Padova, Italy. 1, 2012.

2. ZAŁUSKI T. Cnidion dubii meadows (All. Cnidion dubii Bal.-Tul. 1966) in Poland. Monogr. Bot. 77, 122, 1995 [In Polish].

3. ZAŁUSKI T. 6440 Cnidion dubii meadows. In: W. Mróz (ed.). Monitoring of natural habitats. Methodical Guide. GIOŚ. Warsaw. 3, 64, 2012 [In Polish].

4. ŠEFFER J., JANÁK M., ŠEFFEROVÁ-STANOVÁ V. Management of Natura 2000 habitats Alluvial meadows of river valleys of the Cnidion dubi (6440). Technical Report. European Commission. 17/24, 1, 2008.

5. HÖLZEL N., OTTE, A. Restoration of a species-rich flood meadow by topsoil removal and diaspore transfer with plant material. Appl. Veg. Sci. 6, 131, 2003.

6. KLIMKOWSKA A., DIGGELEN R.V., GROOTJANS A.P., KOTOWSKI W. Prospects for fen meadow restoration on severely degraded fen. In: Perspectives in Plant Ecology, Evolution and Systematics. 12 (3), 245, 2010.

7. TÖRÖK P., VIDA E., DEÁK B., LENGYEL S., TÓTHMÉRÉSZ B. Grassland restoration on former croplands in Europe: an assessment of applicability of techniques and costs. Biodivers. Conserv. 20, 2311, 2011.

8. METSOJA J.A., NEUENKAMP L., PIHU S., VELLAK K., KALWIJ J.M., ZOBEL M. Restoration of flooded meadows in Estonia - vegetation changes and management indicators. Appl. Veg. Sci. 15, 231, 2012.

9. KIRKHAM F.W., BHOGAL A., CHAMBERS B.J., DUNN R.M., TALLOWIN J.R.B. Effects of spreading species-rich green hay on the botanical composition of an agriculturally improved hay meadow in northern England. Grass Forage Sci. 68 (2), 260, 2013.

10. PRACH K., JONGEPIEROVÁ I., ŘEHOUNKOVÁ K. Large-scale restoration of dry grasslands on ex-arable 
land using a regional seed mixture: establishment of target species. Restor. Ecol. 21, 33, 2013.

11. JOYCE C.B. Ecological consequences and restoration potential of abandoned wet grasslands. Ecol. Eng. 66, 91, 2014.

12. ZARZYCKI J., MISZTAL A. Abandonment of farming practices: impact on vegetation. Grassl. Sci. in Europe. 15, 133, 2010.

13. WARDA M., KOZŁOWSKI S. Grassland - a Polish resource. Grassl. Sci. in Europe. 17, 3, 2012.

14. KUCHARSKI L. Vegetation in abandoned meadows in central Poland: Pilsia valley. Case study. Acta Sci. Pol. Agricultura. 14, 37, 2015.

15. TRĄBA C., WOLAŃSKI P., Floristic diversity of meadows communities representing Molinion, Cnidion dubii and Filipendulion Alliance in Poland - threats and protection. Inżynieria Ekologiczna. 29, 224, 2012.

16. GIOŚ. Monitoring of species and natural habitats, with particular focus on the specific areas of habitat protection Natura 2000. Summary of the results of monitoring of natural habitats in 2009-2011. Copyright GIOS. Warsaw. 50, 2012 [In Polish].

17. EUROPEAN COMMISSION. The EU Biodiversity Strategy to 2020. Publications Office of the European Union, ISBN 978-92-79-20762-4, 1, 2011.

18. DIRECTIVE 2004/35/CE of the European Parliament and of the Council of 21 April 2004 on environmental liability with regard to the prevention and remedying of environmental damage. L 143/56, 1, 2004.

19. COUNCIL DIRECTIVE 92/43/EEC of 21 May 1992 on the conservation of natural habitats and of wild fauna and flora. L 206/7, 1, 1992.

20. DIRECTIVE 2009/147/EC of the European Parliament and of the Council of 30 November 2009 on the conservation of wild birds. L 20/7, 1, 2009.

21. BARAŃSKA K. Best Practice Handbook for the conservation of xerothermic grasslands. Coordination Center for Environmental Projects. Warsaw. 1-, 2014 [In Polish].

22. KLIMKOWSKA A., KOTOWSKI W., van DIGGELEN R., GROOTJANS A.P., DZIERŻA P., BRZEZIŃSKA K. Vegetation re-development after fen meadow restoration by topsoil removal and hay transfer. Restor. Ecol. 18, 924, 2010.

23. MAKLES M., PAWLACZYK P., STAŃKO R. Best Practice Handbook for the conservation of wetlands. Coordination Center for Environmental Projects. Warsaw. 29, 2014 [In Polish].

24. SZYMURA M., SZYMURA T.H. Growth, phenology, and biomass allocation of alien Solidago species in central Europe. Plant Species Biol. 30, 245, 2014.

25. SZYMURA M., SZYMURA T.H., WOLSKI K. Invasive Solidago species: how large area do they occupy and what would be the cost of their removal? Pol. J. Ecol. 64, 25, 2016.

26. ŚWIERSZCZ S., SZYMURA M., WOLSKI K., SZYMURA T.H. Comparison of methods for restoring meadows invaded by Solidago species. Pol. J. Environ. Stud. 26, 1251, 2017.

27. ZARZYCKI J. Evaluation of the effect of various systems of extensive utilization on the species diversity of grasslands. Acta Sci. Pol. Agricultura. 2, 27, 2010.

28. JANICKA M. Possibilities of restoration of floristicrich semi-natural grasslands. In Pawluśkiewicz B. (ed.): Management in river valleys in Natura 2000 sites - problems of investment activity. Issued by WULS-
SGGW, Warsaw. ISBN 978-83-75-626-4, 97, 2015 [In Polish].

29. VINCZEFFY I. The effects of some ecological factors on grass yield. Proceedings of the $10^{\text {th }}$ General Meeting of European Grassland Federation. Ås, Norway. 76, 1984.

30. THOMPSON K., BAKKER J.P., BEKKER R.M. The soil seedbanks of North West Europe: methodology, density and longevity. Cambridge University Press. Cambridge. 1, 1997.

31. KIEHL K., KIRMER A., DONATH T.W., RASRAN L., HÖLZEL N. Species introduction in restoration projects - Evaluation of different techniques for the establishment of semi-natural grasslands in Central and Northwestern Europe. Basic Appl. Ecol. 11, 285, 2010.

32. KLIMKOWSKA A., DIGGELEN R.V., GROOTJANS A.P., KOTOWSKI W. Prospects for fen meadow restoration on severely degraded fen. In: Perspectives in Plant Ecology, Evolution and Systematics. 12 (3), 245, 2010.

33. XIONG, S., NILSSON, C. The effects of plant litter on vegetation: a meta-analysis. J. Ecol. 87, 984. 1999.

34. LOYDI A., ECKSTEIN R.L., OTTE A., DONATH, T.W. Effects of litter on seedling establishment in natural and semi-natural grasslands: a meta-analysis. J. Ecol. 101, 454, 2013.

35. ECKSTEIN R., DONATH L. Interactions between litter and water availability affect seedling emergence in four familial pairs of floodplain species. J. Ecol. 93 (4), 807, 2005.

36. HÖLZEL N., OTTE A. Ecological significance of seed germination characteristics in flood-meadow species. Flora. 199, 12, 2004

37. JANICKA M., PAWLUŚKIEWICZ B., MAŁUSZYŃSKA E., SZYDŁOWSKA A. The estimation of some wild flowers seed material from the natural-valuable meadow habitats. Ann. Warsaw Univ. Life Sci. - SGGW, Land Reclam. 48, 329, 2016.

38. JANICKA M. Determination of growth and development of economically important species of forage grasses and Trifolium pratense L. after renovation of the dry meadows by overdrilling. Treatises and Monographs, WULSSGGW. Warsaw. 394, 1, 2012. [In Polish].

39. DONATH T., BISSEL S., HÖLZEL N., OTTE A. Large scale application of diaspore transfer with plant material in restoration practice - Impact if seed and microsite limitation. Biol. Conserv. 138, 224, 2007.

40. CONRAD M., TISCHEW S. Grassland restoration in practice: Do we achieve the targets? A case study from Saxony-Anhalt/Germany. Ecol. Eng. 37, 1149, 2011.

41. KIRMER A., BAASCH A., TISCHEW S. Sowing of low and high diversity seed mixtures in ecological restoration of surface mined-land. Appli. Veg. Sci. 15, 1987, 2012.

42. SCHMIEDE R., OTTE A., DONATH T.W. Enhancing plant biodiversity in species-poor grassland through plant material transfer - the impact of sward disturbance. Appl. Veg. Sci. 15, 290, 2012.

43. SCHMIEDE R., RUPRECHT E., ECKSTEIN R.L, OTTE A., DONATH T.W. Establishment of rare flood meadow species by plant material transfer: Experimental tests of threshold amounts and the effect of sowing position. Biol. Conserv. 159, 222, 2013

44. HEDBERG P., KOTOWSKI W. New nature by sowing? The current state of species introduction in grassland restoration, and the road ahead. J. Nature Conserv. 18, 304, 2010.

45. WALDÉN E., LINDBORG R. Long Term Positive Effect of Grassland Restoration on Plant Diversity - Success or 
Not? PLoS ONE11(5): e0155836. https://doi.org/10.1371/ journal.pone.0155836. 2016.

46. HÖLZEL N., BUISSON E., DUTOITI T. Species introduction - a major topic in vegetation restoration. Appl. Veg. Sci. 15, 161, 2012.

47. ENGST K., BAASCH A., ERFMEIER A., JANDT U., MAY K., SCHMIEDE R., BRUELHEIDE H. Functional community ecology meets restoration ecology: Assessing the restoration success of alluvial floodplain meadows with functional traits. J. Appl. Ecol. 53, 751, 2016.

48. GATTRINGER J.P, DONATH T.W., ECKSTEIN R.L., LUDEWIG K., OTTE A., HARVOLK-SCHÖNING S. Flooding tolerance of four floodplain meadow species depends on age. PLoS ONE. 12 (5), e0176869, https://doi. org/10.1371/journal.pone.0176869. 2017. 
